\title{
Sten Vikner*
}

\section{Trees and Fields and Negative Polarity}

\begin{abstract}
The paper ${ }^{1}$ takes as its point of departure a comparison between two kinds of approaches to clause structure, namely tree analyses like the generative analysis and field analyses like the sætningsskema analysis of Danish of Diderichsen (1946) and many others (or like the topologische Modell analysis of German of Drach 1937 and many others).

The particular difference between the two kinds of analyses which I explore in this paper concerns c-command, which is a relationship between different constituents in a clause. I shall try to show how useful and indispensable c-command is when it comes to accounting for negative polarity items in English, Danish and German, both the more straightforward aspects and the more complex ones, e.g. the so-called NPI-verbs as well as the interaction between NPI-elements and because-clauses.
\end{abstract}

\section{Introduction}

\subsection{Clause structure in tree analyses and in field analyses}

A fundamental difference between various approaches to clause structure is the one between

- tree analyses like the generative analyses that Torben Thrane and I both work with (Thrane 1999, 2003, 2008, 2009, ..., Vikner 1995, 1999a,b, 2007, ...) and

- field analyses like the scetningsskema analyses of Danish of Diderichsen $(1946,1964)$ and many others or like the topologische Modell analyses of German of Drach (1937) and many others.

The difference is the extent to which the various parts of the clause are seen

- as boxes inside other boxes, or

- as pearls on a string, one after the other.

It is a question of extent, as neither of the two can be 0\% or 100\%: Even to Diderichsen (1946), some constituents are inside other constituents (e.g. the object or $\mathrm{N}$ is part of the content field), and even in the generative analyses, some constituents follow other constituents (otherwise trees would only contain mothers and daughters, but no sisters).

The generative tree structure in (1)a is compared to the (simplified) Diderichsen field model of constituent order in modern Danish, Norwegian and Swedish, as illustrated in (1)b for main clauses and in (1)c for embedded clauses:

1 Thank you to Ken Ramshøj Christensen, Jan Engberg, Eva Engels, Alex Klinge, Ramona Römisch-Vikner, Carl Vikner, Johanna Wood, and to the researchers in the University of Cambridge Project on the Development of Negation in the Languages of Europe (principal investigator: David Willis). Thanks also to the audience at the Conference to Mark the Retirement of Torben Thrane in January 2011, Aarhus, to the audience at the SLK Linguistics Seminar in January 2011, Sandbjerg, and to the students in my various classes on negation. Special thanks to Torben Thrane, for support, inspiration and discussion over the many years since the first time I took a class with him in the spring of 1980, during my first year at university.

\footnotetext{
* Sten Vikner

Section for English

Department of Aesthetics \& Communication

Aarhus University

DK-8000 Aarhus C

sten.vikner@hum.au.dk
} 
(1) a

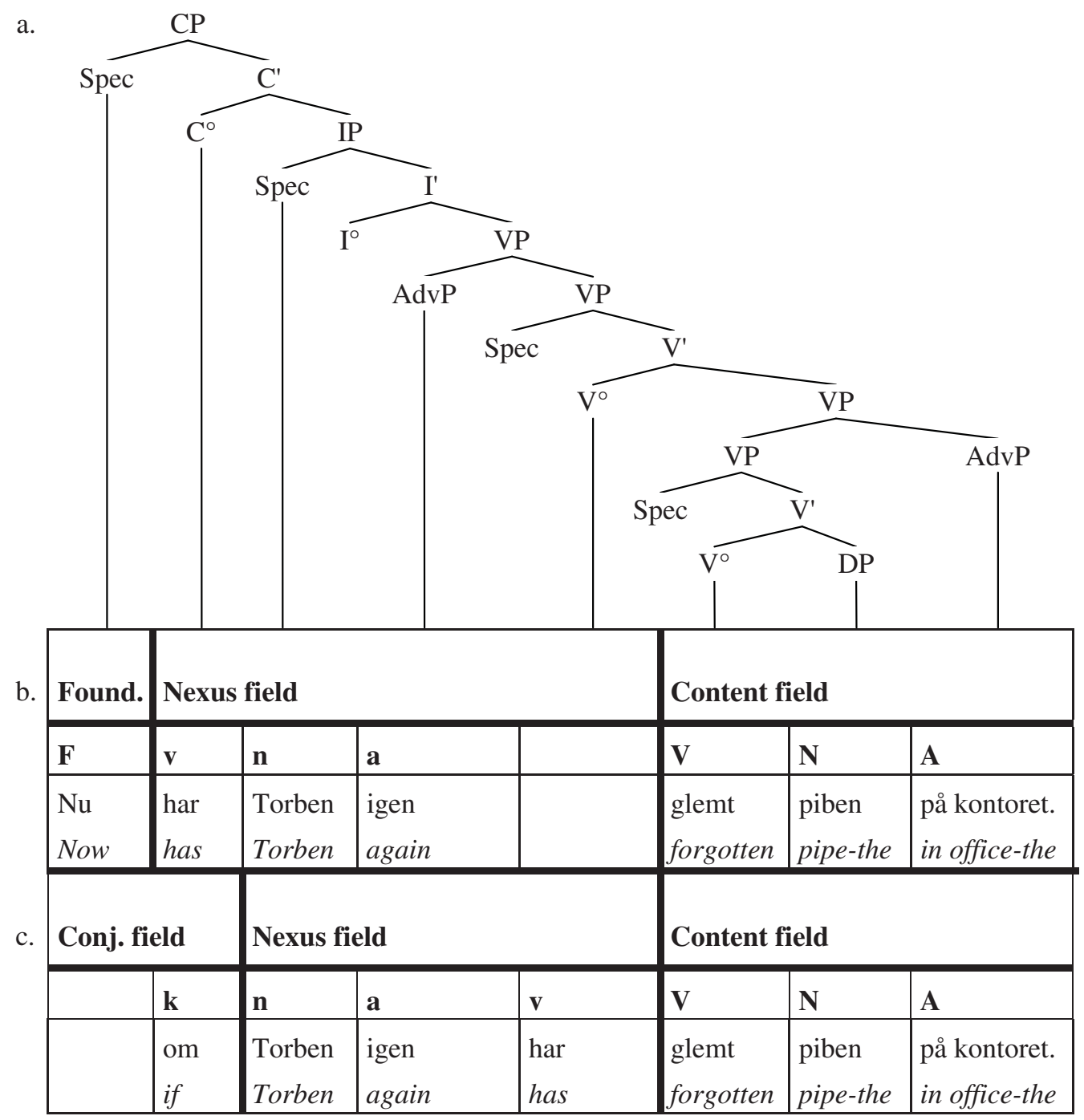

One difference is that in (1)b,c the number of levels and the kinds of constituents that can occur on each level are fixed: There are three levels containing three different kinds of constituents, namely clause - fields - slots / scetning - felter - pladser. In other words, the only possible sister of a field is another field, and the only possible sister of a slot is another slot. In (1)a, on the other hand, this is not the case at all. It is perfectly possible to have a head $\left(\mathrm{X}^{\circ}\right)$ and a phrase (XP) as sisters.

Another difference is that (1)a is based on constituents, as supported by constituency tests. In (1)b,c, however, this is not always the case, as constituency tests will show e.g. that part of V may form a constituent together with $\mathrm{N}$.

Please notice that the difference in (1) between tree analyses and field analyses is NOT one of notation. The tree in (1)a can also be expressed by means of boxes or (or at least square brackets) as in (2)a, and the boxes in (1)b can also be illustrated by means of a tree structure as in (2)b: 
(2) a. [CP [AdvP Nu] [Co har] [IP [DP Torben] [vp [AdvP igen] [vp [vp [vo glemt] [DP piben]] [pp på kontoret]]]]

b.

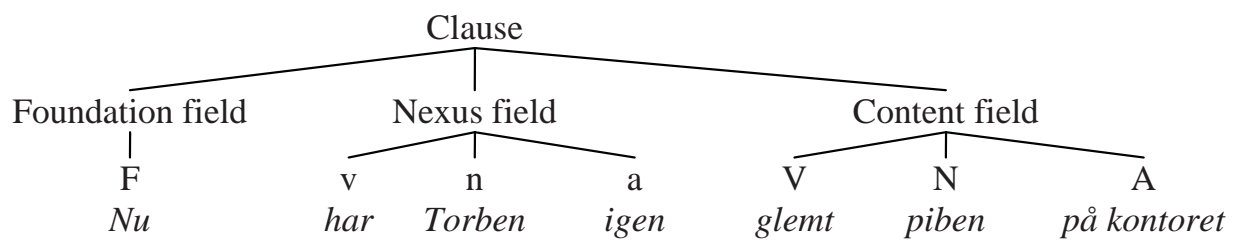

Although I prefer a tree analysis along the lines of (1)a, I willingly admit that field based models like (1)b,c may have e.g. pedagogical use, as in Conrad et al. (1980:182). Cf. also that it is used in a comparison of Danish and English word order by Davidsen-Nielsen/Harder (2000).

Collapsing the Diderichsen model for the main clause with the one for the embedded clause, as in (1)b,c, was not done by Diderichsen himself but by Platzack (1985:71, fn 5) and Heltoft (1986:108). For more details and many more references, see Bjerre et al. (2008).

The differences between the two approaches is not just found in the discussion of Danish and the other Scandinavian languages, it is also very prominent in the discussion of e.g. German and Dutch. Also here both tree analyses and field analyses have a considerable number of advocates.

A generative tree structure of German is found in (3)a, followed by the simplified field model/topological model analyses of German main and embedded clauses in (3)b,c. For more details and more references, see Wöllstein-Leisten et al. (1997) or any of the recent editions of the Duden grammars (e.g. Fabricius-Hansen et al. 2005:879).

(3) a.

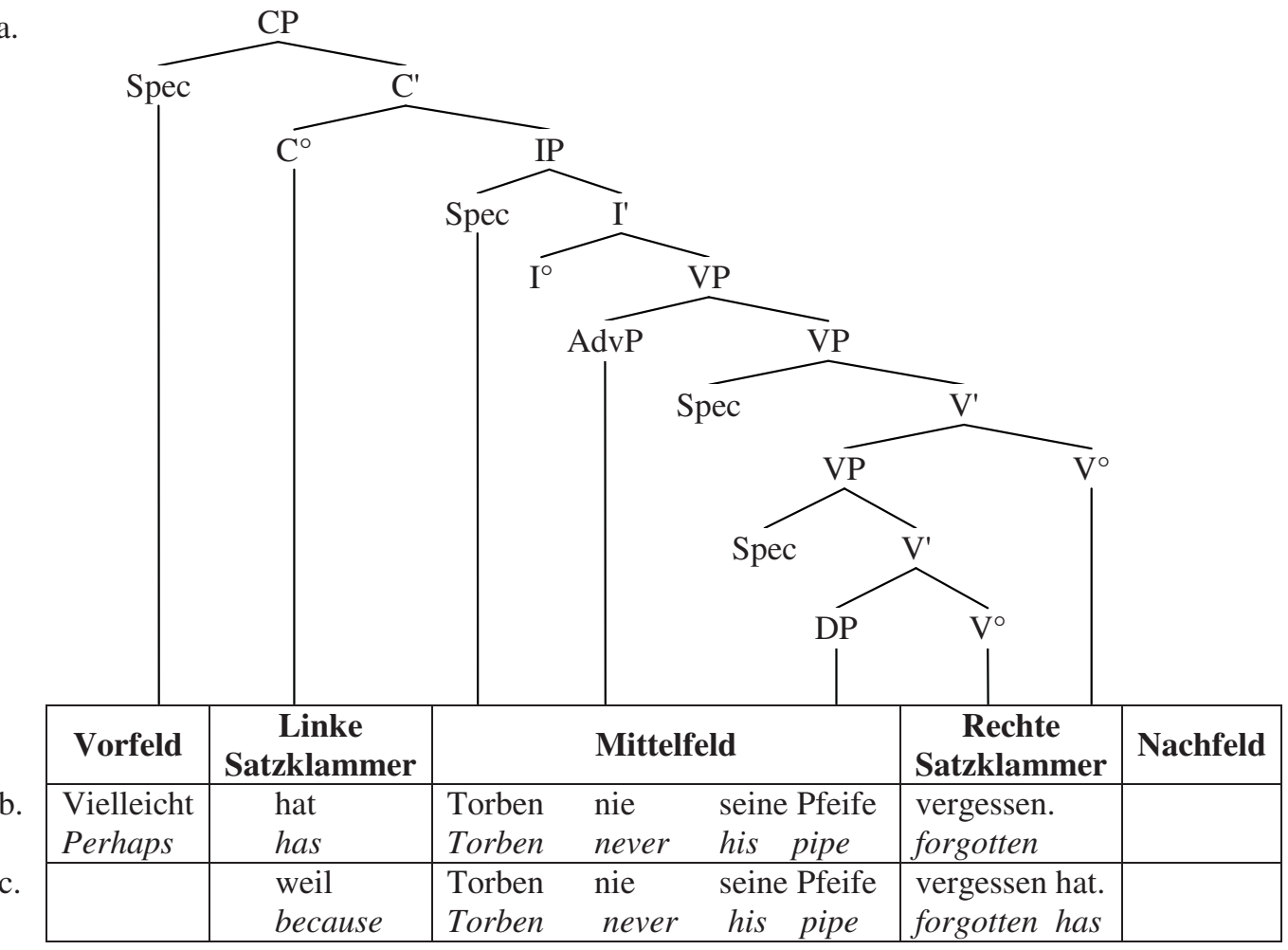

As far as English is concerned, field analyses are not that common, in fact they mainly occur when English is compared to either German or Scandinavian, e.g. Diderichsen (1953) and Hartvigson (1969). However, even though field analyses are thus rather scarce, this does not mean that all analyses of English clause structure employ a tree analysis. In fact, a great many analyses of Eng- 
lish employ something rather close to a field analysis, where most constituents of the clause (e.g. subject, verb, indirect object, object, subject predicate, object predicate, adverbial) are seen as being on the same level, like pearls on a string. Such analyses include Quirk et al. (1985), Preisler (1997), Bache/Davidsen-Nielsen (1997) and Hjulmand/Schwarz (2010).

\subsection{C-command}

In the tree analyses of generative grammar, frequent reference is made to the relation " $\mathrm{C}$-command":

\section{(4) C-command:}

$$
\begin{aligned}
& \text { X c-commands } \mathrm{Y} \text { if and only if } \\
& \text { a. all constituents that contain } \mathrm{X} \text { also contain } \mathrm{Y} \text {, } \\
& \text { b. neither } \mathrm{X} \text { nor } \mathrm{Y} \text { dominates the other. }
\end{aligned}
$$

In other words: if you can get from $\mathrm{X}$ to $\mathrm{Y}$ in the tree by taking one step upwards and then climbing downwards the rest of the way, then X c-commands $\mathrm{Y}$.

C-command may be used to make a number of different generalisations, e.g. concerning where reflexive pronouns may and may not be used -- as described e.g. in my MA-dissertation, which was supervised, incidentally, by a certain T. Thrane (Vikner 1985).

C-command is also crucial to generalisations of the following apparently universal type: A pronoun and a DP may not be coreferential if the pronoun c-commands the DP.

(5) En. a. Torben said that he was retiring. NAME C-COMMANDS PRONOUN,

COREFERENCE POSSIBLE

b. He said that Torben was retiring. PRONOUN C-COMMANDS NAME,

COREFERENCE $\underline{\text { IMPOSSIBLE }}$

(6)

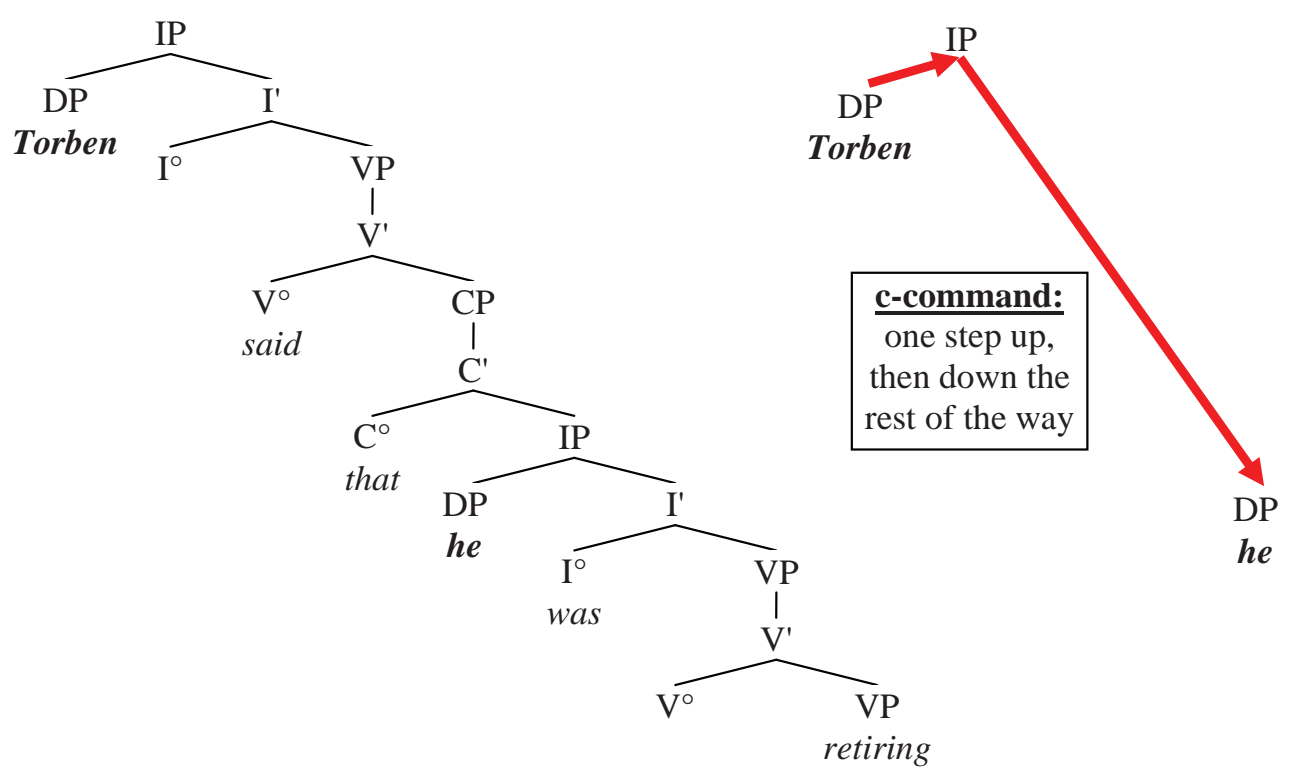

Such generalisations would seem much more difficult to formulate within field model analyses. In a Diderichsen model, (1)b,c, (2)b, the subject would only c-command other elements inside the nexus field, but it would not c-command the object itself, (22), nor any elements inside an object clause, (6). 
In this article, I want to show, with illustrations from the area of negation and negative polarity items, that the generative version of c-command illustrated in (4)-(6) is very useful and that e.g. a purely linear rule would not be able to make the right distinctions.

First, however, we need to consider negative polarity items in detail.

\section{Negative polarity items (NPIs)}

\subsection{Assertive vs. nonassertive vs. negative items}

Quirk et al. (1985: 782) gives the following list of items that fall into one of three groups that they call assertive, nonassertive or negative items.

(7)

\begin{tabular}{|l|l|l|}
\hline Assertive & Nonassertive & Negative \\
\hline some & any & no / none \\
\hline something & anything & nothing \\
\hline somebody & anybody & nobody \\
\hline someone & anyone & no one \\
\hline somewhere & anywhere & nowhere \\
\hline sometimes & ever & never \\
\hline already & yet & \\
\hline still & any more / any longer & no more / no longer \\
\hline too & either & neither \\
\hline to some extent & at all & not at all \\
\hline
\end{tabular}

Assertive items do not change the polarity of a clause (i.e. whether a clause is negative or positive). This can be shown by means of tag questions: If a clause is negative, its tag question has to be positive, and vice versa:

(8) En. a. Torben just bought "Pride and Prejudice", didn't he?

b. * Torben just bought "Pride and Prejudice", did he?

(9) En. a. Torben just bought some books, didn't he?

b. * Torben just bought some books, did he?

Negative items turn a positive sentence into a negative one:

(10) En. a. * Torben didn't buy "Pride and Prejudice", didn't he?

b. Torben didn't buy "Pride and Prejudice", did he?

(11) En. a. * Torben bought no books this week, didn't he?

b. Torben bought no books this week, did he?

Nonassertive items do not change the polarity of a sentence either, but they require the sentence to be negative (certain other contexts work as well: questions, conditional clauses, comparatives, superlatives, ...):

(12) En. a. * Torben bought any books this week, didn't he?

b. Torben didn't buy any books this week, did he?

Quirk et al.'s (1985:782) nonassertive items in (7) are part of what is otherwise known as "negative polarity items" (NPIs). 


\subsection{Negative polarity items are not just idiomatic expressions}

The adverbial expression En. at all / Da. overhovedet / Ge. überhaupt is a negative polarity item (NPI), as it would seem to need a negative element to be possible (or a question/conditional/comparative ...). However, at first glance one might simply think this dependence on negation comes from at all being part of the idiomatic expression not ... at all:

(13) En. a. * Torben understands Icelandic at all.

b. Torben does not understand Icelandic at all.

Da. c. * Torben forstår islandsk overhovedet.

d. Torben forstår ikke islandsk overhovedet.

Ge. e. * Torben versteht überhaupt Isländisch.

f. Torben versteht überhaupt nicht Isländisch.

But this would predict the following to be ungrammatical, as there is no not:

(14) En. a. * Some students in this class understand Icelandic at all.

b. $\quad$ No students in this class understand Icelandic at all.

Da. c. * Nogle studerende på det her hold forstår islandsk overhovedet.

d. Ingen studerende på det her hold forstår islandsk overhovedet.

Ge. e. * Einige Studenten in diesem Seminar verstehen überhaupt Isländisch.

f. $\quad$ Keine Studenten in diesem Seminar verstehen überhaupt Isländisch.

(15) En. a. * Torben understands one of the Baltic languages at all.

b. Torben understands none of the Baltic languages at all.

Da. c. * Torben forstår et af de baltiske sprog overhovedet.

d. Torben forstår ingen af de baltiske sprog overhovedet.

Ge. e. * Torben versteht überhaupt eine von den baltischen Sprachen.

f. Torben versteht überhaupt keine von den baltischen Sprachen.

(16) En. a. * Torben sometimes speaks German at all.

b. Torben never speaks German $\underline{\text { at all. }}$.

Da. c. * Torben taler nogle gange tysk overhovedet.

d. Torben taler aldrig tysk overhovedet.

Ge. e. * Torben spricht überhaupt ab und zu Deutsch.

f. Torben spricht überhaupt nie Deutsch.

The idiomatic expression hypothesis would run into even bigger problems with examples that are not negative in any way at all, like yes/no-questions, as such examples only display part of the idiom not at all, and therefore should be impossible:

(17) En. a. Does Torben understand Icelandic at all?

b. Does Torben not understand Icelandic at all?

Da. c. Forstår Torben overhovedet islandsk?

d. Forstår Torben overhovedet ikke islandsk?

Ge. e. Versteht Torben überhaupt Isländisch?

f. Versteht Torben überhaupt nicht Isländisch?

\subsection{English and Danish NPIs}

Here are a few English NPIs (in addition to the nonassertive items from (7) above): 
(18)

\author{
all that + adj/adv \\ a red cent \\ stand (as verb) \\ bat an eyelid \\ bother to do something \\ budge an inch \\ do a thing about something \\ drink a drop \\ give a damn about something \\ hold a candle to someone \\ move a muscle \\ say a word about something \\ see a living soul \\ sleep a wink
}

Here are two lists, (19) and (20), of negative polarity items in Danish -- the result of a quick check of the electronic version of NuDansk Ordbog (Appel et al. 2002). In the first list, (19), the NPIs can be used both in negated clauses and in questions or conditionals:

(19) a. Arguments

nogetsomhelst

skyggen af noget

en brik / en bønne / en disse / en dyt / en døjt / en flyvende fis / et hak / et klap / et kuk /

et kvidder / et kvcek / en lyd / en meter / et muk / en pind / et pip / en pløk / en skid / en snus / spor / en stavelse / et suk

(money only) en hvid / en klink / en rød reje / en rød øre

b. Adjectives / Adverbs

ncevneværdig(t)

$\operatorname{synderlig}(t)$

c. $\quad$ Place Adverbials

nogen steder

nogetsteds

d. Time Adverbials

nogensinde

på noget tidspunkt

e. Measure adverbials

overhovedet

på nogen måde

i det hele taget

i mindste måde

så meget som ....

f. Verbs

behøve (with infinitive only) døje

fordrage

orke

g. Full VPs

falde nogen ind at ...

finde hoved og hale på/i noget

fortcenke nogen i noget

have en jordisk chance

have noget at skulle have sagt

kimse ad noget

lade noget sidde på sig

lade sig marke med noget

se en hånd for sig

skulle nyde noget

tro sine egne øjne

vokse på trcerne

vcre helt appelsinfri

være med nogens gode vilje

vere nogens afdeling

vcre nogens kop te

vcere noget at rafle/tale om

vere noget galt $i$ at ...

vere nogen ben i noget

vcere på talefod

vœre rigtig klog / vcre vel forvaret

vcere så dårligt/slemt

vere til at blive klog på

vere at foragte

vcre tilfceldet at ... 
In the second list of negative polarity items in Danish, (20), the NPIs can be used in negated clauses but for some reason, they are not so good in questions or conditionals:

(20) a. Adjectives (inside arguments)

det mindste

det fjerneste

b. Adverbial

heller

c. Full VPs

give fem flade øre for noget

give noget ved dørene

have en trevl på kroppen

have opfundet den dybe tallerken

løfte en finger

sige noget to gange

have opfundet det varme vand

stikke op for bollemeelk

have opfundet krudtet

have tone i livet

krumme et hår på nogens hovede

tro nogen over en dørtcerskel

ville røre noget med en ildtang

vere bleg for at ...

vare lutter lagkage

kunne gøre en kat fortrced

kunne tage/snuppe/udstå noget

leegge fingrene imellem

vcre mange sure sild vcerd

vcere tabt bag af en vogn

lagge skjul på noget

vcere til at stå for

vere ved sine fulde fem

\subsection{Licensing of NPIs requires c-command}

The negative polarity element must be c-commanded by the licenser, e.g. by the negative element (see e.g. Fromkin 2000: 223, 404, though see Hoeksema 2000 for certain problems with this analysis).

The subject c-commands the object, but the object does not c-command the subject. Therefore a negative subject can license an NPI-object, but a negative object cannot license an NPI-subject:

(21) En. a. No one understood anything.

b. * Anyone understood nothing.

Da. c. Ingen forstod nogetsomhelst.

d. * Nogensomhelst forstod ingenting.

(22)
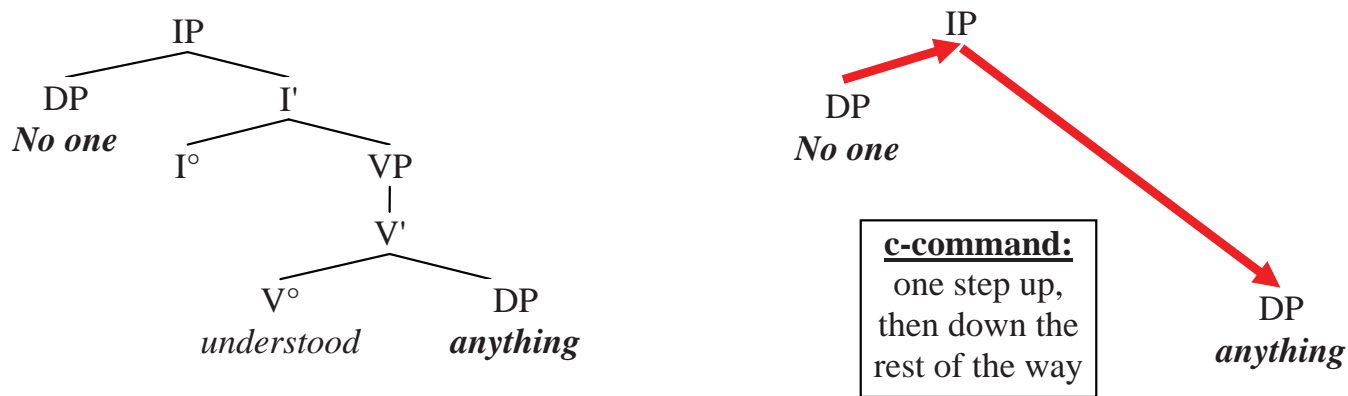

For the purposes of this article ${ }^{2}$ I will simply assume that sentential negation has the same position in the tree as any other sentential adverbial. This has the following consequences for c-command:

2 For a much more detailed discussion of negation in Danish and other languages, including the position of negation, see Christensen (2005, e.g. pp. 28 \& 38ff), and also Christensen (2008). 
(23)

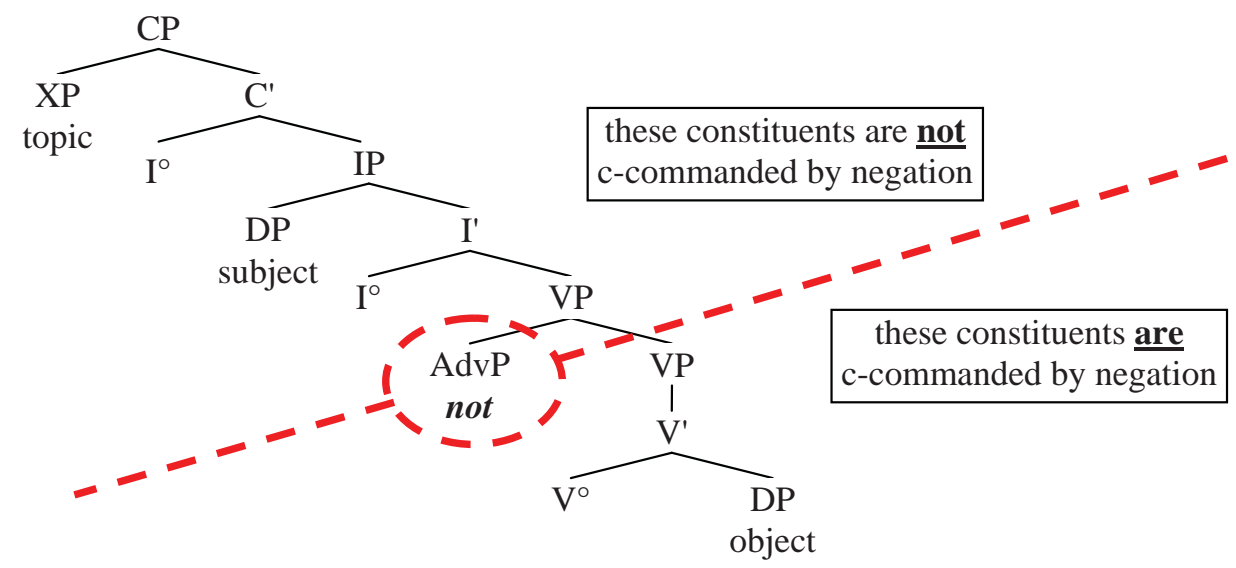

The subject position (IP-spec) is not c-commanded by the negation, (24)a,d, but the position of the logical subject ("the associate") in there-constructions is, (24)b,e.

(24) En. a. * Because anybody wasn't $\quad$ standing outside the door, ...

b. Because there wasn't anybody standing outside the door, ...

c. * Because there was anybody standing outside the door, ...

Da. d. * Fordi nogensomhelst ikke stod uden for døren , ...

e. Fordi der $\quad \underline{\text { ikke }}$ stod nogensomhelst uden for døren , ...

f. * Fordi der stod nogensomhelst uden for døren , ...

The negative polarity element can also be licensed by a negative element in a different clause, provided there is c-command:

(25) En. a. * Because Torben thought that I would ever understand it, ...

b. Because Torben didn't think that I would ever understand it, ...

c. * Because Torben ever thought that I would not understand it, ...

Da. d. * Fordi Torben troede at jeg nogensinde ville forstå det, ...

e. Fordi Torben ikke troede at jeg nogensinde ville forstå det, ...

f. * Fordi Torben nogensinde troede at jeg ikke ville forstå det, ...

Ge. g. * Weil Torben geglaubt hat, dass ich es jemals verstehen würde, ...

h. Weil Torben nicht geglaubt hat, dass ich es jemals verstehen würde, ...

i. * Weil Torben jemals geglaubt hat, dass ich es nicht verstehen würde, ...

A topicalised object is not c-commanded by the negation (i.e. the situation that counts is the one after movement of the object from the object position to topic position in CP-spec, cf. (23)):

(26) En. a.

Torben had not met a living soul

b. * A living soul Torben had not met

c. Not a living soul had Torben met

Da. d. Torben havde ikke mødt en levende sjæl.

e. * En levende sjæl havde Torben $\underline{\text { kke mødt. }}$

f. Ikke en levende sjæl havde Torben mødt.

Ge. g. Torben hatte keine Menschenseele getroffen.

h. * Eine Menschenseele hatte Torben nicht getroffen.

i. Keine Menschenseele hatte Torben getroffen. 
I shall now try to show that the c-command condition on NPI-licensing is necessary, and that it cannot be replaced by a precedence condition ${ }^{3}$. Consider first a set of examples where the NPI $a$ word is both c-commanded and preceded by the licenser:

(27) a. En. Earlier nobody tried

b. Da. Tidligere forsøgte ingen

to understand a word during the classes

c. Ge. Früher hat niemand versucht im Unterricht ein Wort zu verstehen

Consider now a set of examples where the NPI is preceded but not c-commanded by the licenser, because the negation is inside the PP in topic position:
(28) a. En. * [Not long ago]
I tried
to understand a word during the classes
b. Da. * [For ikke ret lang tid siden] forsøgte jeg
at forstå et ord i timerne
c. Ge. * [Vor nicht langer Zeit]
habe ich versucht im Unterricht ein Wort zu verstehen

If precedence was sufficient as a condition on NPI-licensing, (28) should have been grammatical. ${ }^{4}$

\subsection{Licensing of NPI-verbs}

Now I want to look at a special kind of NPIs where c-command might seem not to be required, NPI-verbs.

The first NPI-verbs we shall examine are need in English (not the lexical verb need, but the auxiliary need, i.e. the need that takes an infinitive without to) and its corresponding verbs in Danish and German, behøve/brauchen (only when they embed an infinitive), see (29). When need/behøve/brauchen take a DP-object, they are not NPI-verbs, see (30).

In none of (29)a,c,e do the NPI-verbs seem to be c-commanded by the negation. Nevertheless I think that these verbs need to be licensed by e.g. a negation, as shown by the ungrammaticality of (29)b,d,f. Instead, it must suffice for the licensing of NPI-verbs that the base position of the NPIverb is c-commanded by a licenser (i.e. the NPI-verb must be c-commanded by a licenser before the verb undergoes movement to the left):

(29) En. a. Maybe Torben need not read these books.

b. * Maybe Torben need read these books.

Da. c. Måske behøver Torben ikke læse de her bøger.

d. * Måske behøver Torben læse de her bøger.

Ge. e. Vielleicht braucht Torben diese Bücher nicht zu lesen.

f. * Vielleicht braucht Torben diese Bücher zu lesen.

3 Although the c-command condition on NPI-licensing may in principle also be applied within one of the field analyses, as in (1)b,c, (2)b, or (3)b,c, it would give completely wrong predictions: E.g. the subject would be c-commanded by the negation, something shown in (24)a,d not to be the case, as negation does not license an NPI-subject. This means that the field analyses would have to have a different condition on NPI-licensing, and here an option would be to refer to precedence instead, but as shown in (28), this would not give the right predictions either.

4 To give a complete picture, let me point out a complicating factor. There is a contrast between (28) and (i) below, even though both contain a negation inside a topic: In (i), the NPI is (again) both preceded and c-commanded by the licenser, because here not what is negative is not just the negation but the entire topic - as can be shown e.g. by tag questions or by the English subject-auxiliary inversion in (i)a:

(i) a. En. [At no point in time] did I try to understand a word during the classes

b. Da. [På intet tidspunkt] forsøgte jeg at forstå et ord i timerne

c. Ge. [Zu keiner Zeit] habe ich versucht im Unterricht ein Wort zu verstehen 
(30) En. a. Maybe Torben does not need these books.

b. Maybe Torben needs these books.

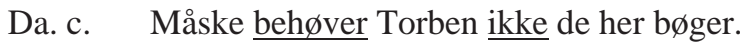

d. Måske behøver Torben de her bøger.

Ge. e. $\quad$ Vielleicht braucht Torben diese Bücher nicht.

f. Vielleicht braucht Torben diese Bücher.

Constituent negation inside the object does not c-command the NPI-verb (here stand/fordrage/ abkönnen), not even when this verb is in its base position, (31)a,c,e, as opposed to (31)b,d,f, which do not contain any NPI-verb at all:

(31) En. a. * Torben can stand [not vodka but whisky].

b. Torben might drink [not vodka but whisky].

Da. c. * Torben kan fordrage [ikke vodka men whisky].

d. Torben kunne drikke [ikke vodka men whisky].

Ge. e. * Torben kann [nicht Wodka sondern Whisky] ab.

f. Torben könnte [nicht Wodka sondern Whisky] trinken.

The NPI-verbs (or at least their base positions) must be c-commanded by a licenser, e.g. the sentential negation:

(32) En. a. Torben can't stand vodka.

b. * Torben can stand vodka.

Da. c. Torben kan ikke fordrage vodka.

d. * Torben kan fordrage vodka..

Ge. e. Torben kann Wodka nicht ab.

f. * Torben kann Wodka ab.

So even though NPI-verbs might seem to be counterexamples to the hypothesis that NPIs require c-command by e.g. a negation, it would seem that they still need a licenser, (29)b,d,f, (32)b,d,f, and that this licenser must c-command the base position of the NPI-verb.

\subsection{NPIs and because-clauses}

Finally I want to examine another case where c-command might seem to be problematic as a licensing condition for NPIs, namely the interaction between NPIs and because-clauses.

Consider examples of the following type (which are also discussed e.g. in Linebarger (1987), in McCawley (1988: 565), and in Ladusaw (1996: 334):

(33) a. En. Torben had not understood my talk

b. Da. Torben havde ikke forstået mit foredrag

because I had used German examples.

c. Ge. Torben hatte meinen Vortrag nicht verstanden, weil ich deutsche Beispiele verwendet hatte.

In spite of what one might think at first glance, these examples are actually ambiguous. Each of them may describe either 
the situation where the use of German examples had prevented Torben from or understanding my talk - after all, he is a professor of English,

(ii) the situation where Torben had understood my talk for a different reason than because of my use of German examples. In other words, the German examples were not a problem - after all, he was once a student of Gunnar Bech's - but what really made him understand the talk was that it was about syntax.

Consider now the following examples, which contain an NPI and which lack such an ambiguity:

(35) a. En. Torben had not understood a thing because I had used German examples.

b. Da. Torben havde ikke forstået et klap fordi jeg havde brugt tyske eksempler.

c. Ge. Torben hatte nicht die Bohne verstanden, weil ich deutsche Beispiele verwendet hatte.

(35) can only be used in the situation described by (34)i, not the one described by (34)ii. This can be shown more clearly if we expand the examples such that only the (34)ii interpretation is possible. Such an expansion is possible for (33), as shown in (36) below, but it is not possible for (35), cf. (37).

(36) a. En. Torben had not understood my talk

b. Da. Torben havde ikke forstået mit foredrag

c. Ge. Torben hatte meinen Vortrag nicht verstanden,

(37) a. En. * Torben had not understood a thing

b. Da. * Torben havde ikke forstået et klap

c. Ge. * Torben hatte nicht die Bohne verstanden, because I had used German examples, but because the talk was about syntax.

fordi jeg havde brugt tyske eksempler, men fordi foredraget handlede om syntaks. weil ich deutsche Beispiele verwendet hatte, sondern weil der Vortrag über Syntax war.

A different set of examples of the same effect are the following:

(38) a. En. Torben had not read the book because he was annoyed.

b. Da. Torben havde ikke læst bogen fordi han var irriteret.

c. Ge. Torben hatte das Buch nicht gelesen, weil er genervt war.

(39) a. En. Torben had not lifted a finger because he was annoyed.

b. Da. Torben havde ikke rørt en finger fordi han var irriteret.

c. Ge. Torben hatte keinen Finger gerührt, weil er genervt war.

Again, (38) is actually ambiguous and may describe both the situation in (40)i and the one in (40) ii. (39), on the other hand, only describes the one in (40)i and not the one in (40)ii.

(40) (i) the situation where being annoyed had prevented Torben from reading the book (he needs peace of mind for reading),

or

(ii) the situation where Torben had read the book for a different reason than because he was annoyed. In other words, it wasn't being annoyed that made him read the book, it was being bored. 
And again this can be shown more clearly if we expand the examples such that only the (34)ii interpretation is possible. Such an expansion is possible for (38), as shown in (41) below, but it is not possible for (39), cf. (42).

(41) a. En. Torben had not read the book

b. Da. Torben havde ikke læst bogen

c. Ge. Torben hatte das Buch nicht gelesen, we because he was annoyed, but because he was bored. fordi han var irriteret, men fordi han kedede sig. sondern weil er gelangweilt war.

(42) a. En. * Torben had not lifted a finger

b. Da. * Torben havde ikke rørt en finger

c. Ge. * Torben hatte keinen Finger gerührt, because he was annoyed, but because he was bored. fordi han var irriteret, men fordi han kedede sig.

weil er genervt war, sondern weil er gelangweilt war.

Presumably, the two interpretations (i.e. (34)i vs. (34)ii, and (40)i vs. (40)ii) differ crucially with respect to whether the because-clause is negated:

- In the (i)-interpretations, the because-clause is not negated (it gives a valid reason for why something did not happen). This is because it is outside the scope of negation, i.e. it is not c-commanded by not - hence it must be higher in the structure than negation (and therefore this is also the only interpretation available when the because-clause is fronted).

- In the (ii)-interpretations, the because-clause is part of what is negated (it gives an invalid reason for why something happened). This is because it is inside the scope of negation, i.e. it is c-commanded by not - hence it must be lower in the structure than negation.

This analysis is supported by the fact that only in the (ii)-interpretations may there be an NPI inside the because-clause itself. The examples in (43) where the NPI the least bit is inside the because-clause thus require the (ii)-interpretations, and therefore they are only really good when this is spelled out, as in (44) (and therefore they also do not allow fronting of the because-clause):

(43) a. En. ? Torben had not skipped my talk

because he was the least bit tired.

b. Da. ? Torben havde ikke pjækket fra mit foredrag fordi han var det mindste træt.

c. Ge. ? Torben hatte meinen Vortrag nicht geschwänzt, weil er im Geringsten müde war.

(44) a. En. Torben had not skipped my talk

b. Da. Torben havde ikke pjækket fra mit foredrag

c. Ge. Torben hatte meinen Vortrag nicht geschwänzt, because he was the least bit tired, but because he had heard it before.

fordi han var det mindste træt, men derimod fordi han havde hørt det før. weil er im Geringsten müde war, sondern weil er ihn schon gehört hatte.

But even if the (ii)-interpretation has the because-clause inside the scope of negation, this does not explain why the (ii)-interpretation is not available in (35) and (39), i.e. it does not explain the ungrammaticality of (37) and (42), which are the expanded version of (35) and (39). Under both interpretations, (i) and (ii), the NPI in (35) and (39) must be taken to be c-commanded by not.

In the extensive literature on this question, there are two kinds of approaches, but they agree that what is special about the (ii)-interpretation is that it is a case of focussing negation, with the focus on the because-clause. 
One approach to why (ii)-interpretation is not available in (35) and (39) (and thus also to why (37) and (42) are ungrammatical) is syntactic in nature, and says that when the because-clause is itself c-commanded by negation, it disturbs the licensing of the NPI (e.g. a thing in (37)). As the because-clause is itself c-commanded by negation and c-commands the NPI, it intervenes in the licensing. For the exact details of such an account, I refer to Linebarger (1987), Guerzoni (2006: 372), and for defence of the idea that focus elements can be interveners, I refer to Kim (2002). A different example of an intervention effect is given in Vikner (1995: 22) and repeated here:

(45) Da. a. Hvad for nogen studerende har du inviteret?

b. Hvad har du inviteret for nogen studerende?

What (for any students) have you invited (for any students)

(= 'Which students have you invited?')

(46) Da. a. Hvad for nogen studerende har du ikke inviteret?

b. * Hvad har du ikke inviteret for nogen studerende?

What (for any students) have you not invited (for any students)

(= 'Which students have you not invited?')

If there is no negation present, it is both possible to front the entire what for students, (45)a, and to front just what, (45)b, the latter perhaps being more colloquial, but nevertheless definitely possible. If negation is present, however, it is still possible to front the entire what for students, (46)a, but it is now not possible to front just what, (46)b. (46)b is an example of an intervention effect, as $i k k e$ is c-commanded by what and c-commands for students.

The other approach to why (ii)-interpretation is not available in (35) and (39) (and thus also to why (37) and (42) are ungrammatical) is semantic in nature. Focus creates a series of alternatives (see Rooth 1992 and many others), cf. e.g. the focussing negation reading of (47)a, where focus is on this morning, and where the alternatives all have the form (47)b:

(47) En. a. Peter didn't arrive in Aarhus this morning

b. Peter arrived in Aarhus at some point in time $\mathrm{X}, \mathrm{X} \neq$ this morning

(The following is strongly simplified, for a much more detailed analysis see e.g. Meier 2001). It would seem that whereas normal negation licences any NPI that it c-commands, focussing negation only licenses an NPI which is inside the focus (i.e. inside the because-clause in (35) and (39)).

This is unexpected, given that a focussing negation c-commands much more than what is inside the focus. What is crucial here is that in the case of focussing negation, the alternatives are all positive, cf. that although (47)a is negative, the alternatives are all positive, (47)b.

The alternatives to the focus readings of (35) and (39) thus do not contain any negation, and therefore the NPI in these alternatives would not be licensed:

(48) En. a. * Torben had not understood a thing because I had used German examples, ... he had understood a thing because the talk was about syntax.

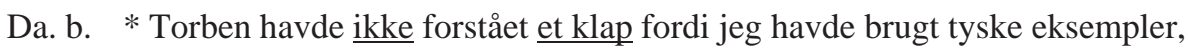
... han havde forstået et klap fordi foredraget handlede om syntaks.

Ge. c. * Torben hatte nicht die Bohne verstanden, weil ich deutsche Beispiele verwendet hatte, ... er hatte die Bohne verstanden, weil der Vortrag über Syntax war. 
(49) En. a. * Torben had not lifted a finger because he was annoyed, ... he had lifted a finger because he was bored.

Da. b. * Torben havde ikke rørt en finger fordi han var irriteret, ... han havde rørt en finger fordi han kedede sig.

Ge. c. * Torben hatte keinen Finger gerührt, weil er genervt war, ... er hatte einen Finger gerührt, weil er gelangweilt war.

If, on the other hand, the NPI is inside the focus, there is no problem, because what is inside the focus is absent from the alternatives, and then it does not matter that there is no negation in the alternatives.

(50) En. a. Torben had not skipped my talk because he was the least bit tired, ... he had skipped my talk because he had heard it before.

Da. b. Torben havde ikke pjækket fra mit foredrag fordi han var det mindste træt, ... han havde pjækket fra mit foredrag fordi han havde hørt det før.

Ge. c. Torben hatte nicht meinen Vortrag geschwänzt, weil er im Geringsten müde war, ... er hatte meinen Vortrag geschwänzt, weil er ihn schon gehört hatte.

Although I have not been able to present a definite analysis of because-clauses, I hope to have shown some of the properties that such an analysis must have, and in particular how any analysis of because-clauses (like any other analysis of anything to do with NPI) must make reference to c-command.

\section{Conclusion}

The objective of this paper was mainly to illustrate a particular difference (concerning the availability of c-command) between two kinds of approaches to clause structure, namely tree analyses like the generative analysis that Torben Thrane and I both advocate and field analyses like the scetningsskema analysis of Danish of Diderichsen (1946) and many others (or like the topologische Modell analysis of German of Drach 1937 and many others).

Having said this, I hope that at least the first part of my paper also illustrated that these approaches have a number of properties in common. I continue to believe that syntacticians would be well advised to look further than the surface of the different formal and functional approaches. Despite the occasionally polemic tone, the various approaches actually have much in common, and they have a lot to learn from each other's insights.

All syntacticians, regardless of theoretical persuasion, are ultimately interested in explaining language data. Given the complex subject matter of the discipline, we need all the help we can get, and therefore none of us can afford to ignore the results reached within 'the opposite camp'.

The particular difference between the tree analyses and the field analyses that was explored in this paper concerned c-command, a relationship between different constituents, which as far as I can see can only be formulated in a tree analysis and not in a field analysis. The question must therefore be how necessary and useful a tool like c-command is, and here I tried to show that it is indeed extremely useful when it comes to accounting for negative polarity items in English, Danish and German, both the more straightforward aspects presented in 2.1-2.4 and the more tricky ones concerning NPI-verbs, section 2.5 and NPI-elements and because-clauses in section 2.6.

\section{References}

Appel, Vibeke/Becker-Christensen, Christian/Heede-Andersen, Susie (eds.) 2002: Politikens nudansk ordbog. Copenhagen: Politikens Forlag.

Bache, Carl/Davidsen-Nielsen, Niels 1997: Mastering English Grammar. Berlin: Mouton de Gruyter. 
Bjerre, Tavs/Engels, Eva/Jørgensen, Henrik/Vikner, Sten 2008: Points of convergence between functional and formal approaches to syntactic analysis. In Working Papers in Scandinavian Syntax 82, 131-166 [online]. www.hum.au.dk/engelsk/engsv/papers/bjer08a.pdf

Christensen, Ken Ramshøj 2005: Interfaces. Negation-Syntax-Brain. PhD dissertation, University of Aarhus [online]. www.hum.au.dk/engelsk/engkrc/Papers/krc-phd.pdf

Christensen, Ken Ramshøj 2008: NEG-shift, Licensing, and Repair Strategies. In Studia Linguistica 62 (2), 182-223.

Conrad, Bent/Einersen, Dorrit/Færch, Claus/Kabell, Inge/Lauridsen, Hanne/Qvistgaard, Ellen/Thrane, Torben /Ørum, Henning 1980: Almene Sproglige Begreber. Copenhagen: University of Copenhagen (= Anglica et Americana 9).

Davidsen-Nielsen, Niels/Harder, Peter 2000: Constituent order in English and Danish. In Copenhagen Studies in Language 25, 39-71.

Diderichsen, Paul 1946: Elementcer Dansk Grammatik. Copenhagen:Gyldendal. 3rd edition 1962. Reprinted 1984.

Diderichsen, Paul 1953: Logische und topische Gliederung des germanischen Satzes. In Diderichsen, Paul 1966: Helhed og Struktur. Copenhagen: G.E.C. Gads Forlag, 52-63.

Diderichsen, Paul 1964: Sætningsleddene og deres stilling - tredive år efter. In Danica, Studier i dansk sprog til Aage Hansen 3. september 1964. Reprinted in Diderichsen, Paul 1966: Helhed og Struktur. Copenhagen: G.E.C. Gads Forlag, 364-379.

Drach, Erich 1937: Grundgedanken der deutschen Satzlehre, Diesterweg, Frankfurt am Main. Reprinted 1963. Darmstadt: Wissenschaftliche Buchgesellschaft.

Fabricius-Hansen, Cathrine/Gallmann, Peter/Eisenberg, Peter/Fiehler, Reinhard/Peters, Jörg/Nübling, Damaris/Barz, Irmhild /Fritz, Thomas A. 2005: Grammatik der deutschen Gegenwartssprache, Duden vol. 4, 7th edition. Mannheim: Bibliographisches Institut.

Fromkin, Victoria (ed.) 2000: Linguistics, An Introduction to Linguistic Theory. Oxford: Blackwell.

Guerzoni, Elena 2006: Intervention effects on NPIs and feature movement: towards a unified account of intervention. In Natural Language Semantics 14, 359-398.

Hartvigson, Hans H. 1969: On the Intonation and Position of the So-Called Sentence Modifiers in Present-Day English. Odense: Odense University Press.

Heltoft, Lars 1986: Topologi og syntaks. En revision af Paul Diderichsens sætningsskema. In Heltoft, Lars/Andersen, John E. (eds.), Scetningsskemaet og dets stilling - 50 år efter, Nydanske Studier og Almen Kommunikationsteori. NyS 16/17, 105-130.

Hoeksema, Jack 2000: Negative Polarity Items, Triggering, Scope and C-Command. In Horn, Laurence/Kato, Yasuhiko (eds.), Negation and Polarity - Syntactic and Semantic Perspectives. Oxford: Oxford University Press, 115-145.

Hjulmand, Lise-Lotte/Schwarz, Helge 2009: A concise contrastive grammar of English for Danish students. Frederiksberg: Samfundslitteratur.

Kim, Shin-Sook 2002: Intervention Effects Are Focus Effects. In Akatsuka, Noriko/Strauss, Susan/Comrie, Bernard (eds.), Japanese/Korean Linguistics 10. Stanford: CSLI, 615-628.

Ladusaw, William 1996: Negation and Polarity Items. In Lappin, Shalom (ed.), The Handbook of Contemporary Semantic Theory. Oxford: Blackwell, 321-341.

Linebarger, Marcia 1987: Negative Polarity and Grammatical Representation. In Linguistics and Philosophy 10, 325387.

McCawley, James 1988: The Syntactic Phenomena of English. Chicago: University of Chicago Press.

Meier, Cécile 2001: NPI-Licensing in Negated Causal Constructions. Unpublished ms, University of Frankfurt [online]. http://web.uni-frankfurt.de/fb10/zimmermann/cecile/PDF-files/because-npi.pdf.

Platzack, Christer 1985: A Survey of Generative Analyses of the Verb Second Phenomenon in Germanic. In Nordic Journal of Linguistics 8.1, 49-73.

Preisler, Ben 1997: Handbook of English Grammar on Functional Principles, 2nd ed. Aarhus: Aarhus University Press.

Quirk, Randolph/Greenbaum, Sidney/Leech, Geoffrey/Svartvik, Jan 1985: A Comprehensive Grammar of the English Language. London: Longman.

Rooth, Mats 1992: A Theory of Focus Interpretation. In Natural Language Semantics 1.1, 75-117.

Thrane, Torben 1999: Forklaringstyper i lingvistikken. In Harder, Peter (ed.), Formel Sprogteori. Nogle udfordringer til den funktionelle tilgang. Copenhagen: Museum Tusculanum Press, 1-26.

Thrane, Torben 2003: Breakstructures. In Journal of Linguistics 39.2, 327-372 [online]. www.sprog.asb.dk/TT/Artikler/Publicerede/JL\%20Breakstructures.pdf

Thrane, Torben 2008: Hvis funktionalisme er svaret, hvad er så spørgsmålet? In Nydanske Studier og Almen Kommunikationsteori. NyS 36, 120-150. 
Thrane, Torben 2009: The Language Faculty - Mind or Brain? In Tidsskrift for Sprogforskning 7, 1-42 [online]. http://ojs.statsbiblioteket.dk/index.php/tfs/article/view/2734/2347

Vikner, Sten 1985: Parameters of Binder and of Binding Category in Danish, Working Papers in Scandinavian Syntax 23 [online]. www.hum.au.dk/engelsk/engsv/papers/vikn85a.pdf

Vikner, Sten 1995: Verb Movement and Expletive Subjects in the Germanic Languages. New York: Oxford University Press.

Vikner, Sten 1999a: Ledstillingen i dansk og government \& binding. In Jensen, Per Anker/Skadhauge, Peter (eds.), Scetningsskemaet i generativ lingvistik. Institut for Erhvervssproglig Informatik og Kommunikation, Syddansk Universitet, Kolding, 83-110 [online]. www.hum.au.dk/engelsk/engsv/papers/vikn99a.pdf

Vikner, Sten 1999b: Vº-til-I flytning og personfleksion i alle tempora. In Islenskt mál 19, 81-128 [online]. www.hum.au.dk/engelsk/engsv/papers/vikn99b.pdf

Vikner, Sten 2007: Teoretisk og komparativ syntaks. In Jørgensen, Henrik/Widell, Peter (eds.), Det bedre argument -Festskrift til Ole Togeby, 7. marts 2007. Aarhus: Wessel \& Huitfeld, 469-480 [online]. www.hum.au.dk/engelsk/engsv/papers/vikn07a.pdf

Wöllstein-Leisten, Angelika/Heilmann, Axel/Stepan, Peter/Vikner Sten 1997: Deutsche Satzstruktur. Tübingen: Stauffenburg. 